\title{
Remembering the commons and reinvigorating them
}

\author{
Review by Krishnendu Ray * \\ New York University
}

Review of Routledge Handbook of Food as a Commons, edited by Jose Luis Vivero-Pol, Tomaso Ferrando, Olivier De Schutter, and Ugo Mattei. (2019). Routledge. Available as hardcover, paperback, and eBook; 424 pages. Publisher's website: https://www.routledge.com/Routledge-Handbook-of-Foodas-a-Commons/Vivero-Pol-Ferrando-SchutterMattei/p/book/9780367628567

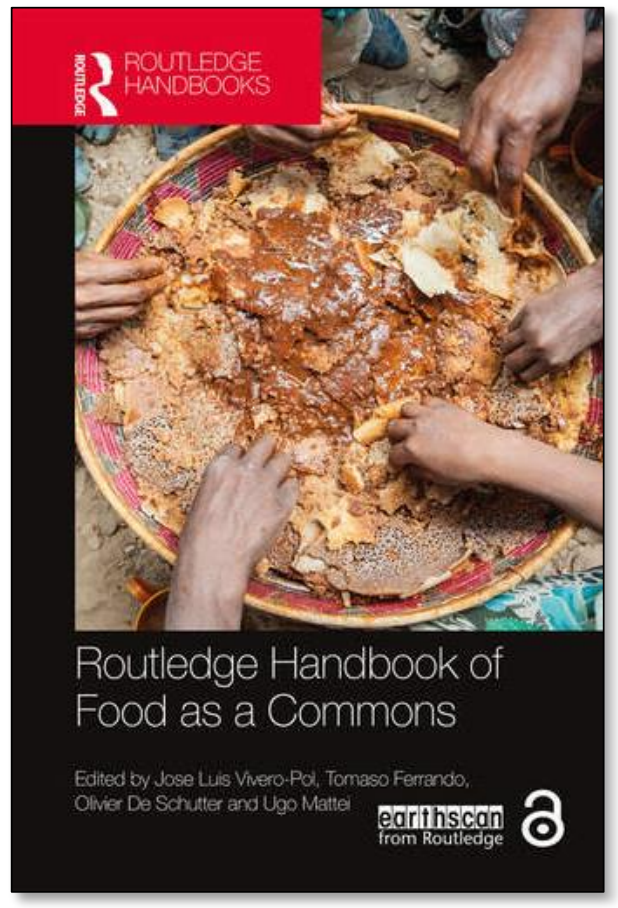

Submitted October 9, 2021 / Published online November 12, 2021

Citation: Ray, K. (2021). Remembering the commons and reinvigorating them [Book review]. Journal of Agriculture, Food Systems, and Community Development, 11(1), 215-217. https://doi.org/10.5304/jafscd.2021.111.008

Copyright (C) 2021 by the Author. Published by the Lyson Center for Civic Agriculture and Food Systems. Open access under CC-BY license.

$\mathrm{T}^{\mathrm{h}}$ he Routledge Handbook of Food as a Commons proposes a normative view of what food ought to be, in the process highlighting instances where and when that potential has been actualized. Food currently is an object to sell and extract private value rather than social sustenance. This book proposes that food be reconceptualized against its

* Krishnendu Ray, Associate Professor, Department of Nutrition and Food Studies, New York University; 411 Lafayette Street, $5^{\text {th }}$ Floor; New York, NY 10012 USA; $\underline{\text { Krishnendu.ray@nyu.edu }}$

Krishnendu Ray is a faculty member in the Department of Nutrition and Food Studies at New York University. He was the chair of the department from 2012 to 2021 . He was a faculty member and the associate dean of liberal arts at the long liberal and recent neoliberal history as property, making a persistent argument about decommodifying food in 24 detailed chapters. It is in recommoning that the more than two dozen authors of the book-many of them leaders in their fieldfind better, alternative ideas about the right to food, global public good, food justice, and food

Culinary Institute of America. He was the president of the Association for the Study of Food and Society from 2014 to 2018. He is the author of The Migrant's Table (2004), The Ethnic Restaurateur (2016), and co-editor of Curried Cultures: Globalization, Food and South Asia (2012). His most recent work is on street vending in global cities with attention to questions of law, livelihood, and liveliness of cities. He is an editorial collective member of the food studies journal Gastronomica. 
sovereignty. They highlight how food as a commodity is currently characterized by its tradable features (appearance, calorie, price, packaging, purchasing power, taste, etc.), thereby denying its non-economic values. It asks two central questions: what would good policies look like if we build on the assumption that food should be the commons, and how do we get there?

The book has five substantive parts, each four to five chapters in length, along with an introduction and conclusion. Part I, "Rebranding Food and Alternative Narrative of Transition," outlines the main normative and empirical arguments for conceiving the commons, as well as multiple understandings of the commons that have emerged among academics and activists. It lays out perspectives on food as a commodity, commons, public good, private good, and right. It identifies "commoning" as articulated by academics, activists, and commoners (the last one, a clever and useful turn of phrase) as the thing to do. The understanding of commons is multiple and phenomenological (meaning developed in varieties of local communities from the inside out). Here we learn how the food system comprises numerous commonswater, soil, labor, infrastructure, and landscapebefore closing with a systematic discussion of economic conceptions of a public good. One chapter develops the feminist theory of "commoning" as care-work, by way of French Regulationist conception and Emmanuel Levinas' other-oriented ethics. Another develops the possibility of an open-source agricultural revolution, with the state playing the role of a partner, although it is unclear how such a state might emerge in the context of lobbying and class interest. This first section underlines both the strength and weakness of this volume. It goes off in multiple directions without seeking a theoretical straitjacket, yet the chapters are additive, either listing one empirical case after the other, or one conceptual argument over another. A reconciliation, or at least critical argumentation between them, could have been attempted at the end of the volume.

Section II builds upon Karl Polanyi's conception of the embeddedness of the market, Amartya Sen's entitlements, and E. P. Thompson's moral economies to develop an argument for developing solidarities to meet human needs. One chapter reaffirms the goal and the pathway to communitybased commons based on a rights system, making charity unnecessary. Another chapter argues about gendering questions of care and the case for cultural integrity by way of the use of human milk. This section closes with an outline of an argument about the commodification of food through the postwar food regime and development of the neoliberal framework, eventually leading to the financialization of food markets. By this point, the book will begin to feel repetitive to the reader.

Section III takes us to the most interesting instances of "commoning" that exist in the world today. It shows how traditional agricultural knowledge, in one instance in Northeastern Spain, belongs to the commons, as does scientific knowledge produced in public institutions under which the whole hybridization program developed — and which has been undermined by the privatization of new knowledge in U.S. universities, and how that can be reversed. A surprising chapter on gastronomy shows how culinary knowledge was privatized on behalf of class and gender with neocolonial consequences. The next chapter, on seeds in the context of the International Treaty on Plant Genetic Resources, gets specific on the problems of governance and collaboration. The section ends with a generative chapter on "commoning" air, water, and food in South Africa that I found promising, allowing the reader to exit the world of mostly Eurocentric instances so far in the volume (in spite of gestures toward Latin American peasant and urban movements). That credential is deepened in Part IV with work on the agroecology movement in Cuba, civil society organization in Canada, waste in Ireland, and self-provisioning in central and eastern Europe. Part V broadens those instances to raise questions about the complicated relationship between food sovereignty and "commoning." Taking the instances of the UK and Italy, more specifically community supported agriculture operations (CSAs), cooperatives, and green spaces in the UK and the Mondeggi Bene Comune in Italy, the authors highlight the long dialectic of privatization and socialization that undergirds much of European agriculture. This is also the section where we learn about civic food networks and real 
utopias. It reminds us of the forgotten world of the commons in the West. We are urged to recall that one-third of the food produced is wasted and that $40 \%$ of unwasted food is fed to livestock and used for biofuels. Private ownership of food-producing land, naturalized in the dominant discourse, is not in fact common in many parts of the world, where over 2.6 billion people live off forests and drylands managed in common. The Food and Agriculture Organization of the United Nations (FAO) estimates that about 500 million hectares around the world are dedicated to heritage agricultural systems managed in mixed proprietary systems, including $5 \%$ of European Union land. In addition, about $30 \%$ of all forest lands are managed by communities. The whole volume is bristling with instances such as the Food Commons in California, the Food Policy Council in Cork, and the Walloon Network of Local Seeds. That is the strength of this volume as a teaching and advocacy tool. Nevertheless, there are important limits.

The language and organization of the volume can be an impediment. The opening paragraph, for instance, rings every leftish ideological bell with reference to the end of history, neoliberalism, the Anthropocene, and the Capitalocene in making the argument that we have witnessed the commodification of food, air, and water. Accurate prognosis is sometimes coded in turgid language reeking of graduate school classrooms and activist meetings. This book will affirm the faith of those who already believe in its arguments, examples, and evidence, such as this reviewer, but by the first page, you realize you have to be an insider to read the next 400-odd pages of text and figures. I am quite sympathetic to its conceptualization and politics, but the book raises concerns about whether this was the best way to organize it. It might have been strengthened by opening it with empirical alternatives, and then moving to the bigger, more abstract, conceptual and critical questions. The editors could have been firmer in eliminating redundancies and repetitions. Finally, it is too persistently critical and not creatively compositional enough. "Commoning" is a verb, and too much of the book is given to critiquing as a mode of doing, especially in the first two-thirds of the volume, rather than showing the reader successful instances of what is being done to get there. It is more successful in breaking things down than building something new and interesting. That might be partly because the volume is too ambitious in hoping to rebuild everything all at once. Yet, that does contribute to its ideological clarity, strengthening its potential for pedagogical use in graduate courses to illustrate the point of view of those interested in turning food from a commodity to the commons. 